\title{
THE VASCULAR FLORA ECOLOGICAL DIVERSITY IN THE MID-FIELD WOODLOTS SITUATED ON THE AGRICULTURAL OUTSKIRTS OF WROCŁAW
}

\author{
Ewa Fudali, Magda Podlaska, Anna Koszelnik-LeszeK
}

E. Fudali, Department of Botany and Plant Ecology, Wrocław University of Environmental and Life Sciences, pl. Grunwaldzki 24a, 50-363 Wrocław, Poland, e-mail: ewa.fudali@upwr.edu.pl;

(D) https://orcid.org/0000-0001-7923-8748 - corresponding author

M. Podlaska, Department of Botany and Plant Ecology, Wrocław University of Environmental and Life Sciences, pl. Grunwaldzki 24a, 50-363 Wrocław, Poland, e-mail: magda.podlaska@upwr.edu.pl; (1) https://orcid.org/0000-0003-2357-6929

A. Koszelnik-Leszek, Department of Botany and Plant Ecology, Wrocław University of Environmental and Life Sciences, pl. Grunwaldzki 24a, 50-363 Wrocław, Poland, e-mail: anna.koszelnik-leszek@upwr.edu.pl; (D) https://orcid.org/0000-0002-5929-9372

\begin{abstract}
Aвsтract. The paper presents an analysis of the ecological requirements and sociological-ecological relations of 403 species of vascular plants recorded in 82 mid-field woodlots located among crop fields in the agricultural outskirts of Wrocław. The aim of the research and analyses was to determine what is the species composition of these woodlots and whether they are ecologically more similar to those situated in environment of farmlands or urban wastelands. The authors assumed the latter. It was found that the mid-field woodlots occupied less than $1 \%$ of arable land and were located exclusively in close proximity to the city's administrative borders, and more than half of them were related to the hydrographic network of the area. Their flora, in general assessment, shows a great variety in terms of water requirements and has the features of woodlots described from typically agricultural areas. This applies to the dominance of forest, shrub and meadow species with a constant, usually not exceeding $20 \%$, share of ruderal plants and a small number of weeds in crops. Thus, the assumption that the flora of the studied woodlots will show signs of ruderalization to a large extent has not been confirmed. $72 \%$ of species occurred in no more than 10 objects, which shows that the described ecological diversity of the flora studied is based on single or few locations. The most frequent species were nitrophilic and in over $50 \%$ they represented a group of shrub communities. The list of the species recorded with estimation of their frequency is provided.
\end{abstract}

KeY wORDs: marginal habitats, forest islands, bryophytes in agriculture landscape, invasive plant species, ancient woodlands indicator plant species, flora of Lower Silesia

\section{INTRODUCTION}

At present there is no doubt that in rural landscapes mid-field woodlots (irrespective of their form, linear or patches) perform important protective functions, both for the abiotic environment and biodiversity, what was documented by many studies carried out in the last decades (i.a. BANASZAK \& CierzNIAK 2000, Le Coeur et al. 2002, Marshall \& Moonen 2002, Schmucki et al. 2002, Gamrat 2012, Fudali et al. 2015, Koszelnik-LeszeK et al. 2015, TomaszewSKA et al. 2016). Most of these studies were carried out in traditionally rural regions. Agricultural lands situated within the administrative borders of cities have usually been overlooked in such research and the structure and biodiversity of their landscape is poorly known. Studies in Warsaw showed that cities develop in many directions at the same time, which means that typical urban structures are pushed deep into the zone of typically agricultural areas (ZIMNY 2005). Taking into account the overall impact of the city development on vegetation (SoLIŃSKA-GórNICKA \& Symonides 1990, Sudnik-Wójcikowska 1991, 1998, ELMQvist et al. 2016) it can be expected that the process of the agricultural lands' urbanization transform both landscape and flora. 
Ewa Fudali, Magda Podlaska, Anna Koszelnik-Leszek

During the last two decades almost $40 \%$ of the agricultural areas in the outskirts of Wrocław has been built or is prepared for investors. The rest area is still used as crop fields (mostly maize and cereals). As they were not floristically studied so far, research on the mid-field woodlots were undertaken in 2019 to find what is species composition of their flora and whether it is ecologically more similar to that found in agricultural lands or in urban wastelands? In this way, we wanted to answer the question, whether the fragments of agricultural landscape preserved in the city's outskirts retain their attributes in the context of multi-functionality of agricultural areas (WILKIN 2008) or whether they are losing them as a result of urbanization pressure? We assumed the latter.

The paper presents ecological analysis of the flora found in the mid-field woodlots situated within crop fields in suburbs of Wrocław in relation to the species requirements to the moist condition in the habitats, their trophy and sociological-ecological relations.

\section{MATHERIALS AND METHODS}

\section{STUDY AREA CHARACTERISATION}

Wrocław is one of the biggest towns in Poland which area amounts to $293 \mathrm{~km}^{2}$ and is inhabited by about 640,000 people. The city is situated in the south-western part of the country, in a flat area formed by the Odra River and its five tributaries, whose waters occupy about $3 \%$ of the city area (Lewicki, ed. 2014). The climate is transitional, between oceanic and continental. Winters are short (65 days) and mild. The average annual precipitation in the 20th century was $583 \mathrm{~mm}$. The average annual temperature is $9^{\circ} \mathrm{C}$, and the annual temperature amplitude is $19.2^{\circ} \mathrm{C}$. The most frequent winds are from a westerly direction $(27.6 \%$ of days a year; the highest speed of $4.4 \mathrm{~m} / \mathrm{s}$ during winter and $3.4 \mathrm{~m} / \mathrm{s}$ in summer) and from the south $(23.1 \%)$.

The area of Wrocław, like in most old and big cities, is spatially diversified in terms of land use and almost $25 \%$ of the city area is currently occupied with the crop fields (ZaKrZeWsKa-PóŁtorak 2017). But still in the first decade of the 21st century, agricultural lands made up $47 \%$ of the city's area (LEWICKI, ed. 2014). In recent decades they have been partly fallowed and, more recently, systematically built-up with residential and housing estates. The resources of non-build soils that are constantly used for agriculture are unevenly distributed in the area of Wrocław. Only narrow peripheral strips occur in the southern part of the city (the best black lands) and in the eastern (quite fertile, but waterlogged river muds and glial soils). Much larger areas are occupied by agricultural land in the western (fertile and moist river marshes) and north-western sectors of Wrocław (acidic light soils, weak in terms of agriculture) (KABAEA \& CHODAK 2002). The forests, located mainly in the north-west, cover $7.5 \%$ of the city area.

\section{WOODLOTS STUDIED}

The studies included all the mid-field woodlots occurring in a crop field landscape, outside built-up areas (villages or new house-settlements) and public roads covered with asphalt. Altogether, 82 midfield woodlots were identified. They were located peripherally in parts $\mathrm{W}, \mathrm{N}$ and $\mathrm{E}$ of the city, close to the city's administrative borders. Any such object was found in the agricultural areas situated deeper towards the center.

In the field nine various forms of woodlots were recognised: 1) row of trees and shrubs along the roadside ditch -6 objects; 2 ) row of trees and shrubs along field road without ditch $-1 ; 3$ ) row of trees and shrubs along the border of the fields (without roads and ditches) - 3;4) single or double-rows of trees along the watercourses and ditches in the field -22 ; 5) 5-7 m wide strips with trees and shrubs along the watercourse or ditch -16 ; 6) forest cultivation among fields -4 ; 7) trees and shrubs on the ruderal habitat -3 ; 8) afforested patches with a water reservoir or a preserved fragment of the watercourse -6 and 9) afforested patches among crop fields -21 , quite often in a small depression of the land. For the further analysis, they have been reduced to three basic types: $(\mathrm{P})$ surface clusters of trees characterised by a compact shape -34 objects, (LP) strip plantings 5-7 m wide, in the vicinity of a watercourse or ditch -16 and (L) single-row, rarely double-row, tree plantings distinguished by a strongly elongated shape, not exceeding 2-3 m wide - 32; these were consistent with the classifications of other authors (GAMRAT \& BURCZYK 2007). The size (length and area) of the woodlots studied was very differentiated: in the P-type objects an area amounted from 0.001 to 8.47 ha, on average $0.98 \mathrm{ha}$, in the LP-type woodlots it ranged from 0.004 to $1.2 \mathrm{ha}$, on average $-0.48 \mathrm{ha}$. The length of L-type objects was from 67 to $1025 \mathrm{~m}$, on average $233 \mathrm{~m}$.

\section{FIELD STUDIES AND THE DATA DESCRIPTION}

The research objects (mid-field woodlots) were initially selected on the basis of satellite photos (www.1) and then verified in the field. The verification was aimed at determining whether the object is a tree stand among crop fields. Floristic research was carried out in the growing season of 2019 using the route method by recording all observed species separately in each of the layers of vegetation (trees, shrubs, herbaceous plants, bryophytes). The area within the range of tree crowns (vertical projection) was assumed as the area of a given object. Most of the plant species were identified in the field. Doubtful or 
unknown species were collected and then species recognised via use of the microscope in the laboratory.

The classes of relative frequency were determined according to the own scale: very frequent - the species was present in at least $75 \%$ of the sites, frequent $-50-74.9 \%$, rare $-25-49.9 \%$, very rare - in less than $25 \%$ of the sites but in more than one site, sporadical species - recorded only in one site.

The ecological requirements of the plant species in relation to water regime and trophy of habitats were defined using the ecological indicator values by ElLENBERG et al. (2001) and the sociological-ecological affiliation of species was determined according to conception by MAAReL (1971) using the available phytosociological literature (OBERDORFER 2001, MATUSZKIEWICZ 2008). The ancient woodlands plant indicators were recognized according to Dzwonko \& Loster (2001). Nomenclature of the vascular plant species follows Mirek et al. (2002). Invasive alien plant species were recognised according to TOKARSKA-Guzik et al. (2012).

\section{RESULTS}

\section{GENERAL COMMENTS ON THE FLORA AND THE RELATIVE ABUNDANCE OF SPECIES}

In total, 423 species of plants were recorded (Appendix - Table 1). In terms of taxonomy at the division-level, flora showed little diversity: apart from the dominant angiosperms, there were found: one representative of gymnosperms, three - ferns, three - horsetails, two - liverworts and 18 - mosses. The share of bryophytes was negligible, both in terms of the size of the occupied area and the number of objects in which their presence was recorded -21 , therefore this group was omitted in further analysis. The following bryophyte species were identified: liverworts - Lophocolea bidentata (L.) Dumort. (1 object) and Marchantia polymorpha L. (2), mosses - Amblystegium serpens (Hedw.) Schimp. (1), Atrichum undulatum Web. et Mohr. (6), Brachytheciastrum velutinum (Hedw.) Ignatov et Huttunen (7), Brachythecium albicans (Hedw.) Schimp. (2), Brachythecium rutabulum (Hedw.) Schimp. (13), Brachythecium salebrosum (Hoffm. ex F. Weber et D. Mohr) Schimp. (2), Ceratodon purpureus (Hedw.) Brid. (1), Cirriphyllum piliferum (Hedw.) Grout. (2), Eurhynchium hians (Hedw.) Sande Lac. (3), Eurhynchium striatum (Hedw.) Schimp. (2), Kindbergia praelonga (Hedw.) Ochyra (1), Plagiomnium affine (Blandow ex Funck) T. Kop. (3), Plagiomnium undulatum (Hedw.) T. Kop. (6), Plagiothecium nemorale (Mitt.) A. Jaeger (2), Pleurozium schreberi (Willd. ex Brid.) Mitt. (2), Pseudoscleropodium purum (Limpr) M. Fleisch. ex Broth. (2), Pohlia nutans (Hedw.) Lindb. (1) and Polytrichastrum formosum (Hedw.) G.L. Sm. (1).

Considering the plant morphology, herbaceous species dominated (83\% of flora). Among plants with woody shoots, 40 species of trees and 42 bushes were recorded, and 15 of them were alien (e.g. Aesculus hippocastanum, Fraxinus latifolia, Quercus palustris, Q. rubra, Padus serotina, Robinia pseudoacaccia, Cydonia oblonga, Sorbaria sorbifolia, Rosa rugosa, Rhus typhina). With regard to the length of the life cycle, perennial plants had the largest percentage incidence $(78 \%)$, including 48 species of geophytes.

The number of species found in individual woodlots varied considerably, ranging from 17 to 122; on average -50 . Such large differences in the species richness of individual sites were reflected in the analysis of the relative frequency of species. No species occurred in all the sites and only 18 in at least half of the studied objects (including Crataegus monogyna, Sambucus nigra, Urtica dioica, Solidago gigantea and Quercus robur in more than $75 \%$ of the sites). Thus, very rare species had a dominant incidence. Quite numerous was also the group of species recorded only in one site (class of sporadical species), constituting $23 \%$ of the identified vascular flora (Fig. 1).

\section{ECOLOGICAL AND SOCIOLOGICAL- -ECOLOGICAL SPECTRUM OF FLORA}

The analysis of ecological requirements in relation to the habitat's humidity showed that the core of the flora are mesophilic plants (species of moderately humid habitats), although the presence of plant species preferring habitats with extreme humidity conditions and plants neutral to water regime was also noted (Fig. 2, Table 1).

All xerophytes represented the classes of very rare and sporadic species (Fig. 2, Table 1). Similarly, the group of aquatic plants consisted almost entirely of very rare and sporadic species. The exception was Phragmites australis with a slightly higher frequency (22 objects - class of rare species). Greater differentiation as to the relative frequency of occurrence

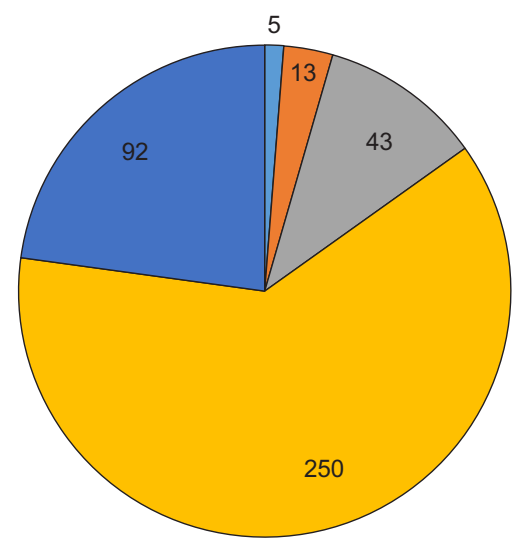

$\square$ very frequent $\quad \square$ frequent $\quad \square$ rare $\quad \square$ very rare $\quad \square$ sporadical

Fig. 1. Incidence of species in the distinguished relative frequency classes 
was found in the groups of higrophytes and species neutral in relation to the humidity of the habitat, although very rare species also dominated in them (Fig. 2). The most common higrophytes were, among others, trees: Padus avium (39 objects), Salix fragilis (36) and Alnus glutinosa (33), and among herbaceous plants: Humulus lupulus (46), Phalaris arundinacea (27), Poa trivialis (26), Symphytum officinale (25) and Lysimachia vulgaris (24).

Regarding the trophic conditions of the habitats, species with moderate requirements and neutral were also predominant, but nearly one third of plants showed a preference for habitats that are rich and very rich in nitrogen compounds (Fig. 3). Nitrophilic plants showed differentiated relative frequency, but it should be noted that in the classes of very frequent and frequent species they had about $60 \%$ share, and in the remaining ones no more than $30 \%$.

The presented differentiation of the requirements for humidity and trophy of the habitat is reflected in the sociological-ecological diversity of the flora. Representatives of 10 sociological-ecological groups were found (Fig. 4).

In each of the woodlots, the presence of forest and forest-scrub species was recorded (Fig. 5), and in almost all (80) there were meadow and ruderal plants. In a large number of sites, the presence of species from the groups of segetal plants (63 objects) as well as utility and ornamental plants (60) was also recorded, and in more than half of the

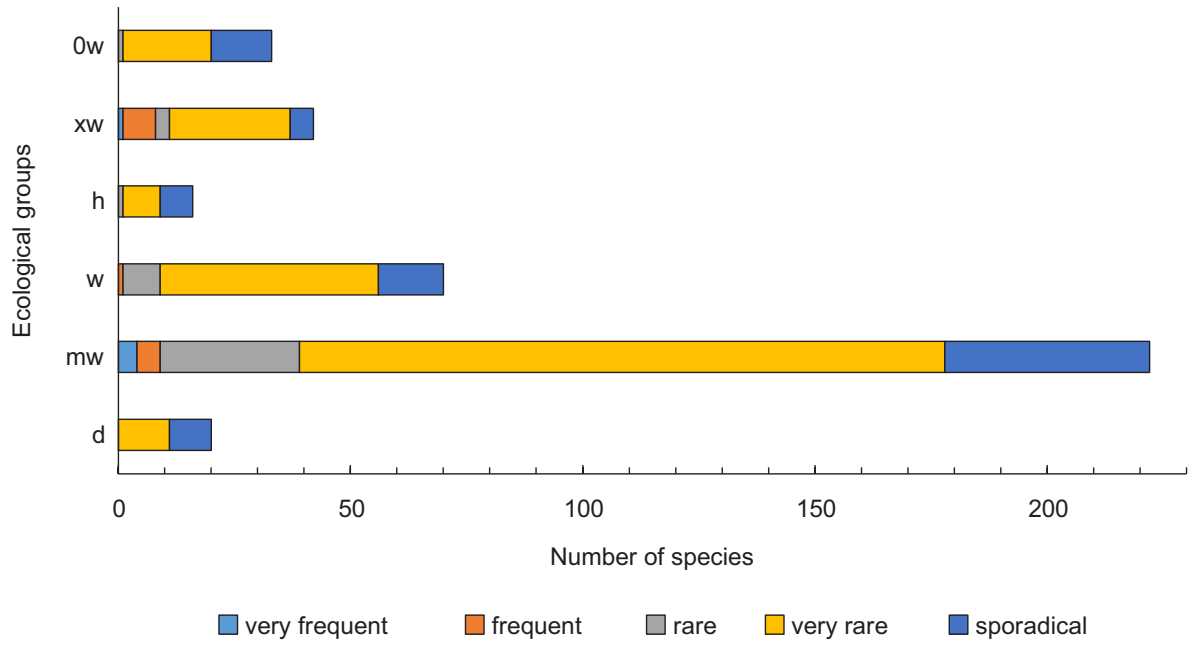

Fig. 2. The number of plant species in ecological groups of different requirements in relation to the humidity of the habitat, with information of their relative frequency

Explanations: $\mathrm{d}$ - plants in dry habitats (Ellenberg's index value 1-3), $\mathrm{mw}$ - plants in moderately humid habitats (4-6), w - plants in humid and wet habitats (7-9), h - aquatic plants (10-12), xw - plants neutral in relation to changes in humidity, $0 \mathrm{w}$ - no data on moisture requirements.

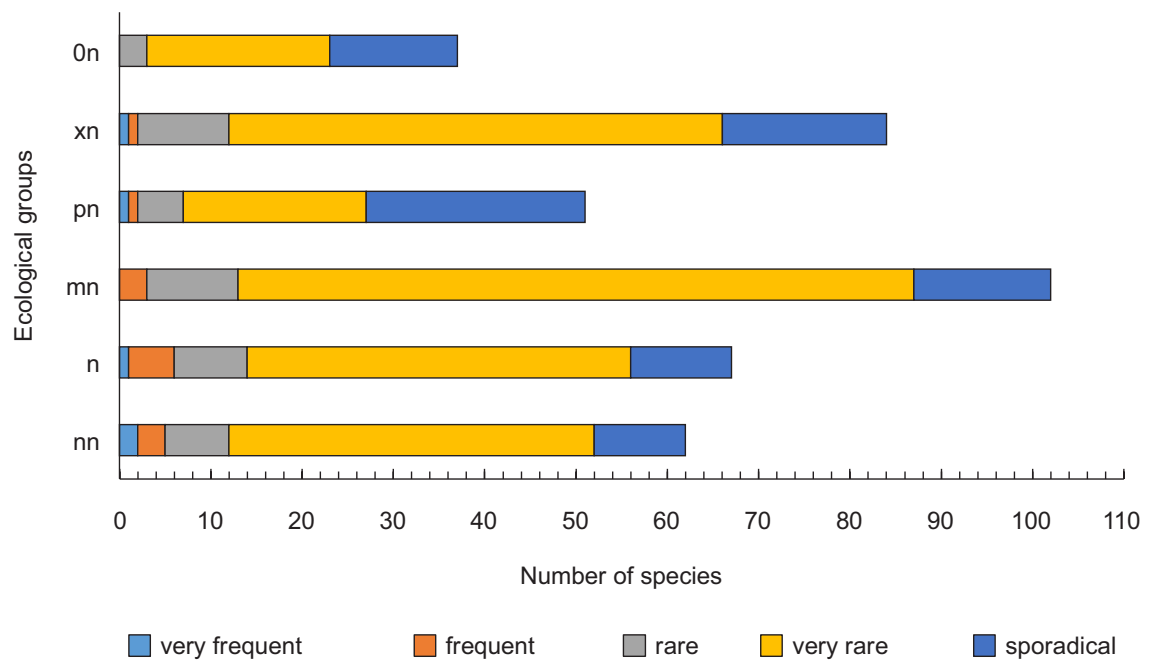

Fig. 3. The number of plant species in ecological groups of different requirements in relation to the fertility of the habitat, with information of their relative frequency

Explanations: $\mathrm{nn}$ - plants of very rich habitats (Ellenberg's index value 8-9), $\mathrm{n}$ - plants of rich habitats (7), mn - plants of moderately rich habitats (4-6), pn - plants of poor habitats (1-3), xn - plants neutral in relation to the fertility of the habitat, On - no data on trophic requirements. 


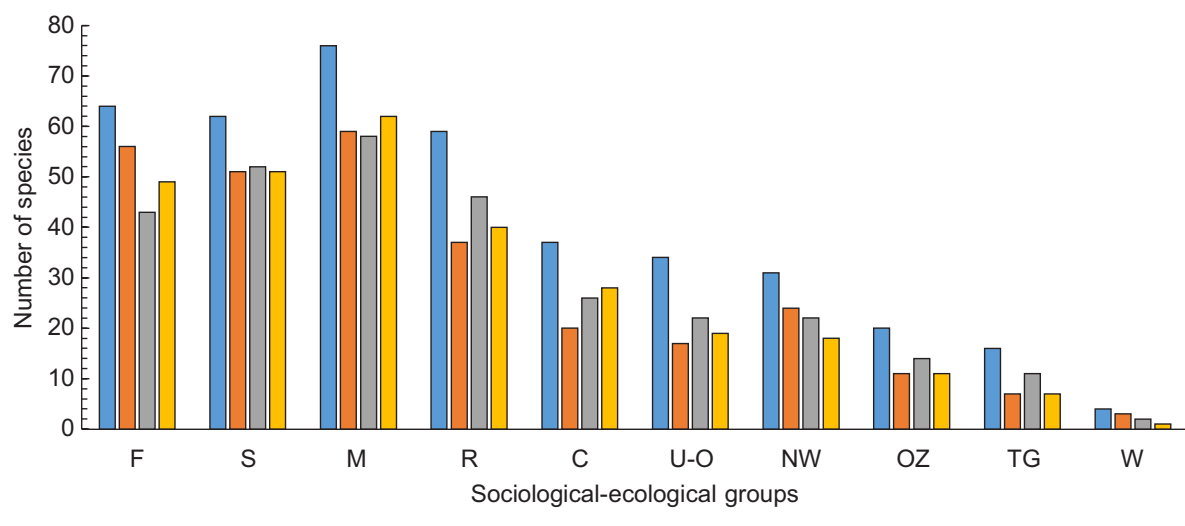

$\square$ TOTAL $\square \mathrm{P} \square \mathrm{L} \square \mathrm{LP}$

Fig. 4. The number of species representing the distinguished sociological-ecological groups in the flora studied, in total and in relation to individual types of mid-field woodlots

Explanations: sociological-ecological groups: $\mathrm{C}$ - plants of segetal communities, $\mathrm{F}$ - plants of forest communities, $\mathrm{M}$ - meadow plants, TG - plants of termophilic grassland communities, NW - plants of communities developing near water, OZ - communities of the forests' herbal fringes, $\mathrm{R}$ - plants of ruderal communities, $\mathrm{S}$ - plants of scrub communities, $\mathrm{U}-\mathrm{O}$ - utility and ornamental plants, $\mathrm{W}-$ aquatic communities; object types: P - surface, L - row, LP - strip.

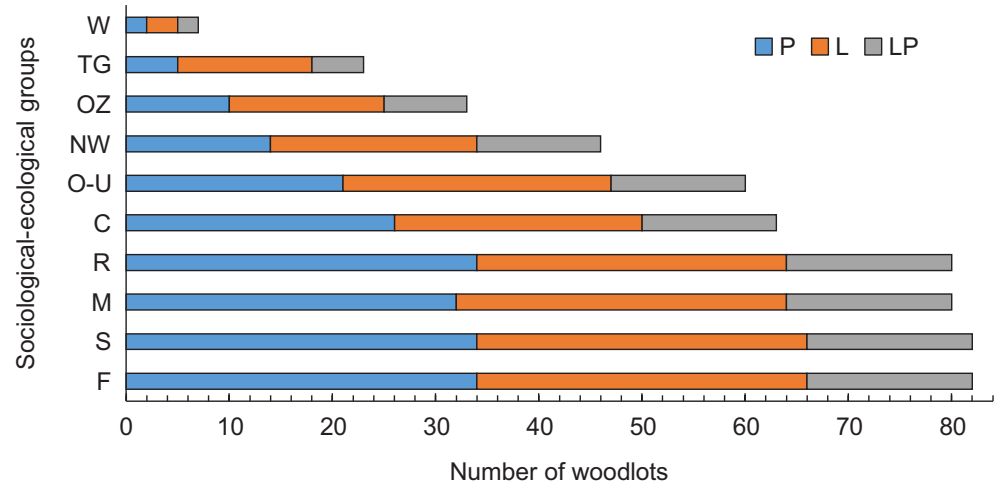

Fig. 5. Number of woodlots in which species representing individual sociological-ecological groups occurred, with the indication of the woodlot's type

Explanations: symbols as in Figure 4.

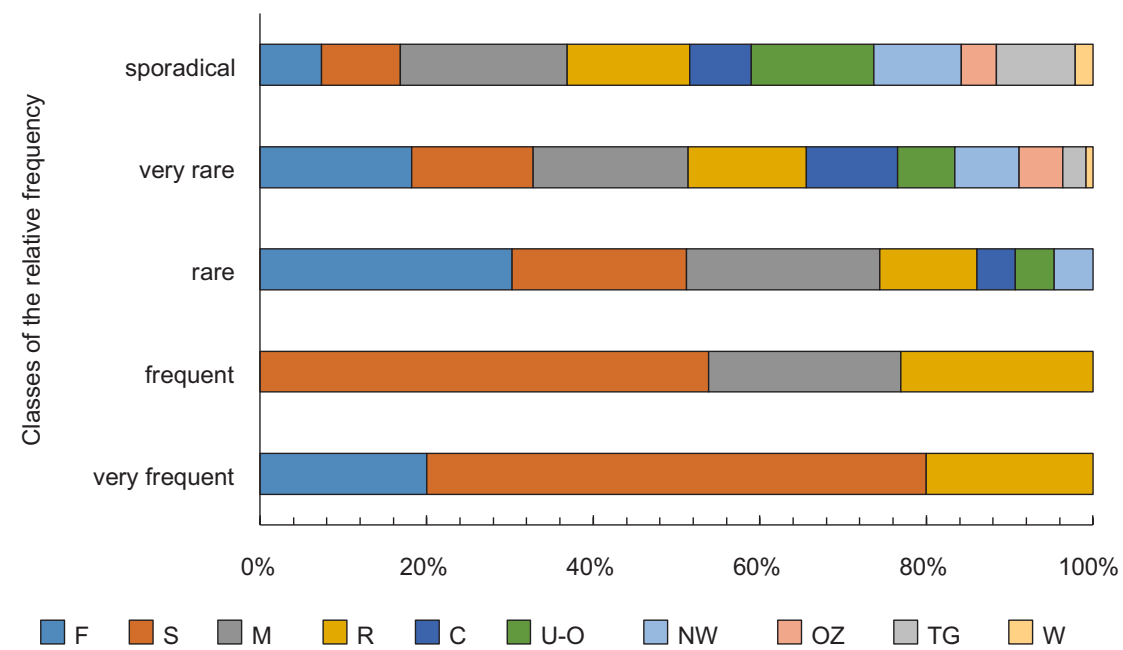

Fig. 6. Percentage incidence of species representing sociological-ecological groups in the relative frequency classes Explanations: symbols as in Figure 4. 
woodlots - plants associated with aquatic communities (46). The occurrence of species representing other sociological-ecological groups was limited to a much smaller number of objects (Fig. 5).

The largest group (76 species) were meadow plants (Fig. 4). Their percentage incidence in the flora of individual woodlots ranged from 2 to $40 \%$, most often in the range $11-20 \%$. The total number of plants associated with forest communities was slightly lower (64) and their share in the flora of individual sites was within a wide range of $6-54 \%$, with almost a half of them exceeding $20 \%$. It is worth adding that 30 species from the forest group were plants showed as indicators of ancient woodlands, with among others: Brachypodium sylvaticum, Convallaria majalis, Elymus caninus, Equisetum sylvaticum, Majanthemum bifolium, Pulmonaria obscura, Solidago virgaurea (Table $1)$. The number of plants in scrub communities was similar to the number of forest species (62). Their percentage incidence in the flora of individual objects was always higher than $10 \%$ and reached $46 \%$, and most often ranged between $21-40 \%$. The group of ruderal plants was less numerous (59); their percentage share in the flora of individual objects ranged from 3 to $40 \%$, and most often was between 11 and $20 \%$. Representatives of three sociological-ecological groups: segetal (37), ornamental and usable plants (34) and those associated with communities developing near water (31) were recorded in over half of the sites, but their percentage incidence in the flora of individual woodlots usually did not exceed $10 \%$. Like species representing other groups.

More than half of the plants belonging to the classes of very frequent and frequent species were associated with shrub communities (Fig. 6), the rest of the very frequent class represented the groups of ruderal and forest plants, and of the frequent class groups of meadow and ruderal plants. Representatives of these four groups also made up most of the rare species class. The greatest sociological-ecological diversity was shown by plants of the classes of very rare and sporadic species.

\section{COMPARISON OF FLORA FOUND IN INDIVIDUAL TYPES OF WOODLOTS}

The number of species found in each type of woodlots was almost the same in types LP and P, respectively:

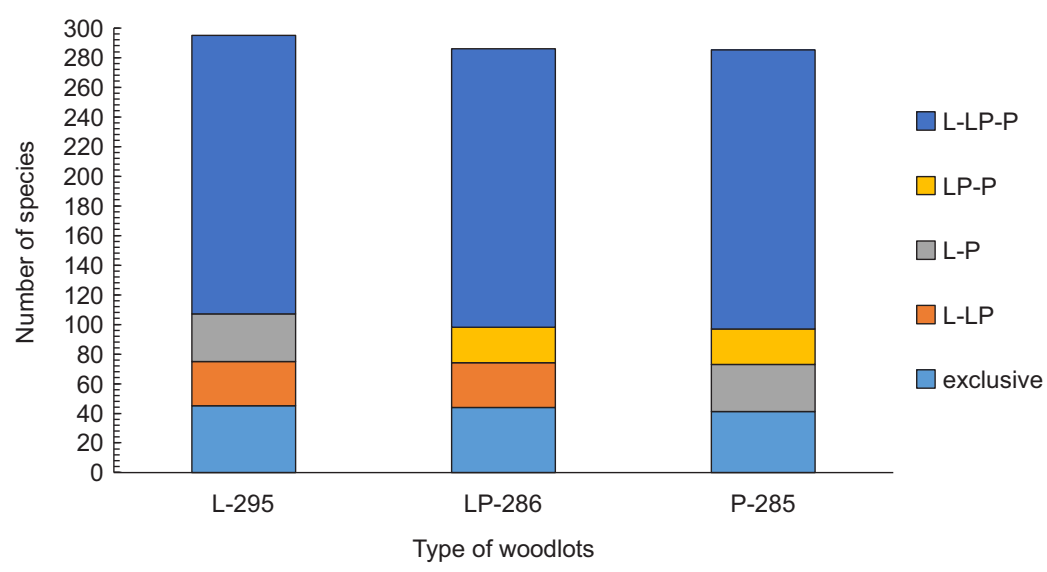

Fig. 7. The incidence of species that occurred exclusively in one of the given type of woodlots, in two types and in each Explanations: symbols as in Figure 4.

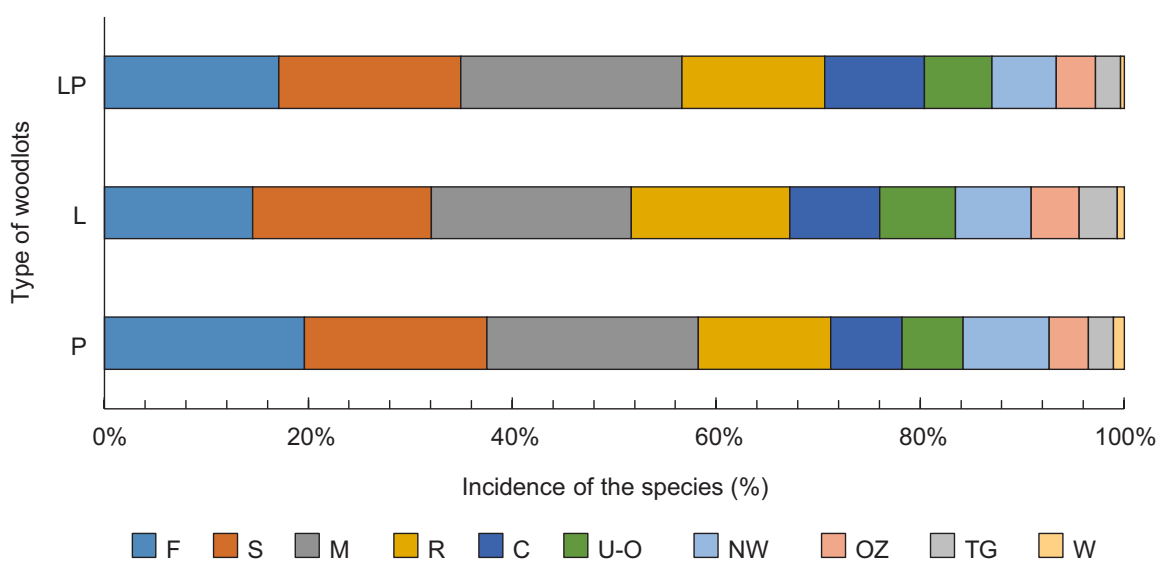

Fig. 8. Percentage incidence in the flora of individual type of woodlots of the species representing distinguished sociological-ecological groups

Explanations: symbols as in Figure 4. 
286 and 285 , while in type $\mathrm{L}$ there were more of them - 295. In all three types, individual objects differed greatly in terms of the number of species: in P-type, the minimum number was 18 and the maximum -89 , with an average of 42 species; in L-type: min. 17, max. 122, on average 50; in the LP-type: min. 29, max. 107, on average 58 .

The comparison of the lists of species compiled for each of the woodlots type showed that nearly half of the flora (188 species) occurred in each type. This number included all plants classified as very frequent, frequent and rare, and $51 \%$ of very rare. Only in one type of the woodlots occurred, respectively: $\mathrm{L}-45$ species (including 30 sporadic ones), LP - 44 (44), P - 41 (28). The P-type had more species in common with the L-type than LP-type (Fig. 7).

The numbers of species representing individual sociological-ecological groups (Fig. 4) and their percentage incidence in the flora of each of the three types of woodlots (Fig. 8) differed, although to a small extent. These differences were most clearly marked in the group of forest species, which had a much higher share in the P-type than in the others (Fig. 8). This type was also distinguished by the largest number of species associated with water-related communities (although only 6 objects were situated close to water reservoir) and the smallest number of segetal, ruderal, ornamental and usable species. Compared to the other types, there is also a noticeable greater number and share of segetal species in the woodlots of LP-type and the ruderal and those occurring in termophilic grassland communities in the L-type.

\section{DISCUSSION AND CONCLUSIONS}

Research has shown that in the agricultural outskirts of Wrocław, mid-field woodlots occur almost exclusively near the city administrative borders, and their total area does not exceed $1 \%$ of the agricultural area (SzYMANOwski 2020, unpublished). Despite the relatively small acreage and quite close proximity to intensively emerging housing estates, the woodlots studied have features of marginal habitats occurring in a typical agricultural landscape, which include, among others, significant species richness of plants with diverse ecology, most of which are permanent (perennial) species (Loster 1991, Marshall \& MooNEN 2002, GAMRAT 2012). As in southern Norway (EDVARDSEN et al. 2010), the studied flora consisted of both common species in the country as well as endangered and rare species in the Lower Silesia region (FudALi et al. 2020). The similarity to the woodlots located in agricultural areas was clearly visible with regard to the sociological-ecological diversity of flora. This applies to the dominance of forest, scrub and meadow elements with a constant, usually not exceeding $20 \%$, share of ruderal plants and a small number of weeds in crops (WójciK \& WasiŁOWSKA 1994, Marshall \& Moonen 2002, Edvardsen et al. 2010, Koszelnik-LeszeK et al. 2015). Thus, our assumption that the flora of the studied woodlots will show signs of ruderalisation in large extent has not been confirmed neither in the general assessment nor in relation to the individual types of woodlots. The distinguishing feature was the nearly $10 \%$ share of ornamental and usable species, probably resulted from abandonment of biological waste from gardens and crops in these objects, and from intentional plantings.

In addition to the relatively high species richness and ecological diversity, the studied flora is characterised by a significant incidence of species with a low relative frequency $-72 \%$ of species were recorded in no more than 10 objects. Among them were representatives of all sociological-ecological groups, including all species associated with aquatic communities and almost all occurring in: termophilic grassland communities, segetal communities, communities of the forests' herbal fringes, communities developing near water as well as utility and ornamental plants. Thus, the described sociological-ecological and ecological diversity of the flora of the studied woodlots is based on single or few locations, what at the same time indicates a high degree of its threat.

Noteworthy is the occurrence of species considered as plant indicators of ancient woodlands. This role is assigned to nearly half $(48 \%)$ of the forest plants found (Dzwonko \& Loster 2001). Twenty one of them showed a clear preference for occurrence in P-type and LP-type, which seems obvious (OrczewSKA 2009, FudALI et al. 2015). But L-type woodlots were also habitats for many of the ancient woodlands indicator plants, e.g. Ajuga reptans, Brachypodium sylvaticum, Dactylis polygama, Galeobdolon luteum, Melampyrum nemorosum, Polygonatum multiflorum, Scrophularia nodosa, Stellaria nemorum. The relative frequency of most species in this group was very low, they occurred in no more than 10 sites.

Distribution of the studied woodlots was strongly related to the hydrographic network - more than half of the objects (50) were located in the vicinity of natural watercourses or ditches. This resulted in a nearly $20 \%$ share of higrophytes and hydrophytes in the studied flora, including three species, Carex buekii, Oenanthe fistulosa and Salvinia natans, with a high threat status in Lower Silesia (FudALI et al. 2020). Unfortunately, many of them (28\%) were recorded in only one locality. The importance of in-field ditches, watercourses and water bodies for the preservation of rare species not found in other farmland habitats was pointed out by many researchers (e.g. GAMrat et al. 2007, Herzon \& Helenius 2008, Kryszak et al. 2011, ARCZYŃSKA-Chudy 2012, TomAsZEWSKA et al. 2016 ). Our studies has shown that even with far-reaching landscape fragmentation, these habitats can support 
specific flora. In the agricultural areas adjacent to Wrocław, the share of woodlots along the ditches was different. They appeared in a similar number as the surface woodlots and those associated with communication routes (OrŁowsKi \& NowAK 2005).

The location of the studied objects among fertilized cultivated fields is the most likely cause of the presence of a large group of nitrophilic plants (LE Coevr et al. 2002). They formed the majority of the frequent and very frequent species classes, but the core of the group of nitrophytes consists of plants classified as very rare and sporadic. These plants retain nitrogen compounds flowing or blown away from the fields by building them into their tissues. In this way, they also protect surface waters against eutrophication (ARCZYŃSKA-CHUDY 2012). An additional source of nitrogen compounds for the flora of the objects studied can be biological and municipal waste, unfortunately often abandoned there. Certainly, the treatment of mid-field woodlots as landfills for various types of waste cause to the destruction of flora and habitats (GAMrat 2012), and thus may be a factor in the sporadic occurrence of many species.

Protecting of the agro-ecosystems environment is an important function expected to mid-field woodlots. Many studies indicate their importance in protecting soils against erosion, water retention, modifying the microclimate of fields or maintaining populations of insects and birds beneficial for crops (BanaszaK \& Cierzniak 2000, Le Coeur et al. 2002, Marshall \& Moonen 2002, Schmucki et al. 2002, Symonides 2010, Chappell \& LaVAlle 2011, LindBorg et al. 2014 - and literature cited therein). A rich and ecologically diverse flora is indispensable for this. The presented research has shown that in the agricultural outskirts of Wrocław, there are still preserved floristically and ecologically diverse mid-field woodlots, the presence of which enables them to perform the above-mentioned functions, although their percentage incidence in the crop field acreage is very small $(0.87 \%)$. At least some of them deserve conservation due to the presence of protected species (Centaurium erythraea, Epipactis helleborine, Salvinia natans), endangered species (Bromus arvensis, B. ramosus, Lathyrus latifolius, Oenanthe fistulosa) and rare species in the Lower Silesia region (Carex buekii, Euphorbia lucida, Silaum silaus) (Fudali et al. 2020). However, it should be added here that these woodlots are also places of migration for many species of invasive alien plants, such as e.g. Solidago canadensis, S. gigantea, Padus serotina, Robinia pseudoacaccia, Impatiens parviflora, Rosa rugosa, Bidens frondosa, Reynoutria japonica, R. $\times$ bohemica and Acer negundo (TOKARSKA-GuZIK et al. 2012).

\section{ACKNOWLEDGMENTS}

We thank Prof. Mariusz Szymanowski (Institute of Geography and Regional Development, Wrocław
University) for determining the total area of the studied objects and their percentage share in the area of arable fields in Wrocław.

\section{REFERENCES}

ARczyŃSKa-Chudy E. (2012): Małe zbiorniki śródpolne jako bariery biogeochemiczne. In: R. Gołdyn, N. Kuczyńska-Kippen (eds). Rola zbiorników wodnych w krajobrazie rolniczym. Fundacja Biblioteka Ekologiczna, Poznań: 152-161.

BANASZAK J., CierzniaK T. (2000): Ocena stopnia zagrożeń i możliwości ochrony owadów w agroekosystemach. Wiadomości Entomologiczne 18, Suplement 2: 73-94.

Chappell M.J., Lavalle L.A. (2011): Food security and biodiversity: can we have both? An agroecological analysis. Agriculture and Human Values 28(1): $3-26$.

Dzwonko Z., Loster S. (2001): Wskaźnikowe gatunki roślin starych lasów i ich znaczenie dla ochrony przyrody i kartografii roślinności. Prace Geograficzne 178: 119-132.

Edvardsen A., Halvorsen R., Norderhaug A., PederSEN O., RYDGREN K. (2010): Habitat specificity of patches in modern agricultural landscapes. Landscape Ecology 25: 1071-1083.

Ellenberg H., Weber H.E., Düll R., Wirth V., WerNER W. (2001): Zeigerwerte von Pflanzen in Mitteleuropa. Scripta Geobotanica 18: 1-262.

ElmQvist T., ZipPerer W.C., GiIneralp B. (2016): Urbanization, habitat loss and biodiversity decline. Solution pathways to break the cycle. In: K.C. Seto, W.D. Solecki, C.A. Griffith (eds). The Routledge Handbook of Urbanization and Global Environmental Change. Routledge, London-New York: 139-151.

Fudali E., Koszelnik-LeszeK A., Tomaszewska K., Podlaska M., Pruchniewicz D. (2015): Gatunki roślin wskaźnikowych starych lasów we florze wysp leśnych na terenach rolniczych południowo-zachodniej Polski. Zeszyty Naukowe Uniwersytetu Przyrodniczego we Wrocławiu: Biologia i Hodowla Zwierząt. 78(610): 15-34.

Fudali E., Podlaska M., Koszelnik-Leszek A. (2020): Zadrzewienia śródpolne na rolniczych peryferiach Wrocławia jako enklawy zagrożonych i rzadkich w regionie gatunków roślin. In: K. Pentoś (ed.). Rolnictwo XXI wieku - problemy i wyzwania 2020. Idea Knowledge Future, Świebodzice: 1726.

GAMrat R. (2012): Studia nad różnorodnością śródpolnych wysp środowiskowych w dorzeczu Iny. Rozprawa habilitacyjna. Wydawnictwo Zachodniopomorskiego Uniwersytetu Technologicznego w Szczecinie, Szczecin: 1-99.

Gamrat R., BurczyK P. (2007): Skład gatunkowy śródpolnych zadrzewień grupowych na Równinie Weł- 
tyńskiej. Woda-Środowisko-Obszary Wiejskie 7(1): 45-59.

Gamrat R., Burczyk P., WesoŁowski P. (2007): Szata roślinna skarp i poboczy rowów melioracyjnych w centralnej części Równiny Wełtyńskiej. WodaŚrodowisko-Obszary Wiejskie 7(1): 61-77.

Herzon I., Helenius J. (2008): Agricultural drainage ditches, their biological importance and functioning. Biological Conservation 141(5): 1171-1183.

Kabaza C., Chodak T. (2002): Gleby. In: K. Smolnicki, M. Szykasiuk (eds). Informator o stanie środowiska Wrocławia 2002. Dolnośląska Fundacja Ekorozwoju, Wrocław: 66-73.

Koszelnik-Leszek A., Podlaska M., Fudali E., TomasZEWSKA K. (2015): Różnorodność flory śródpolnych wysp leśnych w krajobrazie rolniczym południowo-zachodniej Polski w odniesieniu do grup socjo-ekologicznych. Zeszyty Naukowe Uniwersytetu Przyrodniczego we Wrocławiu: Rolnictwo 63(612): 29-56.

KrysZak A., KLARZyŃSKa A., Kryszak J., StrychalsKa A., SZYMAŃCZYK J. (2011): Zbiorowiska roślinne skarp kanałów i rowów melioracyjnych. Woda-Środowisko-Obszary Wiejskie 11(33): 159-177.

Le Coeur D., Baudry J., Burel F., Thenail C. (2002): Why and how we should study field boundary biodiversity in an agrarian landscape context. Agriculture, Ecosystems and Environment 89: 23-40.

LEwICKI Z. (ed.). (2014): Środowisko Wrocławia. Informator 2014-2016. LEMITOR Ochrona Środowiska, Wrocław.

Lindborg R., Plue J., Andersson K., Cousins S.A.O. (2014): Function of small habitat elements for enhancing plant diversity in different agricultural landscapes. Biological Conservation 169: 206213.

Loster S. (1991): Różnorodność florystyczna w krajobrazie rolniczym i znaczenie dla niej naturalnych i półnaturalnych zbiorowisk wyspowych. Fragmenta Floristica et Geobotanica 36(2): 427-457.

MAARel E. vAN DER (1971): Florastatistieken als bijdrage tot de evaluatie van natuurgebieden. Gorteria 5: 176-188.

Marshall E.J.P., Moonen A.C. (2002): Field margins in northern Europe: their functions and interactions with agriculture. Agriculture, Ecosystems and Environment 89: 5-21.

Matuszkiewicz W. (2008): Przewodnik do oznaczania zbiorowisk roślinnych Polski. Wydawnictwo Naukowe PWN, Warszawa.

Mirek Z., PięKoś-Mirkowa H., Zając A., Zając M. (2002): Flowering plants and pteridophytes of Poland. A checklist. Vol. 1. Biodiversity of Poland. W. Szafer Institute of Botany, Polish Academy of Science, Kraków.

Oberdorfer E. (2001): Pflanzensoziologische Exkursionsflora für Deutschland und angrenzende
Gebiete. Verlag Eugen Ulmer, Stuttgart (Hohenheim).

OrczewsKa A. (2009): Age and origin of forests in southwestern Poland and their importance for ecological studies in man-dominated landscapes. Landscape Reserach 34(5): 599-617.

OrŁowsKI G., NowAK L. (2005): Species composition of woody vegetation of three types of mid-field woodlots in intensively managed farmland (Wroclaw Plain, south-western Poland). Polish Journal of Ecology 53(1): 25-36.

Schmucki R., De Blois S., Bouchard A., Domon G. (2002): Spatial and temporal dynamics of hedgerows in three agricultural landscapes of southern Quebec, Canada. Environmental Management 30(5): 651-664.

SolińsKa-Górnicka B., Symonides E. (1990): Effect of a large city on the structure of coenoelements in a natural woodland in Warsaw. Vegetatio 88: 163-176.

SuDNIK-WójcikowsKa B. (1991): Synanthropization indices of urban floras - an attempt at definitions and assessment. Acta Societatis Botanicorum Poloniae 60(1-2): 163-185.

Sudnik-Wójcikowska B. (1998): Czasowe i przestrzenne aspekty procesu synantropizacji flory na przykładzie wybranych miast Europy Środkowej. Wydawnictwo Uniwersytetu Warszawskiego, Warszawa.

Symonides E. (2010): Znaczenie powiązań ekologicznych $w$ krajobrazie rolniczym. Woda-Środowisko-Obszary Wiejskie 10(4): 249-263.

TOKARSKa-GuZiK B., DajDoK Z., Zając M., ZajĄC A., Urbisz A., Danielewicz W., HoŁdyński C. (2012): Rośliny obcego pochodzenia w Polsce. Generalna Dyrekcja Ochrony Środowiska, Warszawa.

Tomaszewska K., Podlaska M., Koszelnik-Leszek A., FudALI E. (2016): Floristical diversity of midfield water bodies in the rural landscape of Lower Silesia (SW Poland). Zeszyty Naukowe Uniwersytetu Przyrodniczego we Wrocławiu: Rolnictwo 116(617): 75-90.

WiLkin J. (2008): Wielofunkcyjność rolnictwa i obszarów wiejskich. In: M. Kłodziński (ed.). Wyzwania przed obszarami wiejskimi i rolnictwem w perspektywie lat 2014-2020. Instytut Rozwoju Wsi i Rolnictwa PAN, Warszawa: 9-20.

Wójcik Z., WasıŁowsKa A. (1994): Synantropizacja wysp leśnych w krajobrazie rolniczym. Wiadomości Ekologiczne 40(2): 77-85.

ZaKrZeWSKa-PóŁtorak A. (2017): W kierunku miasta zwartego? Przemiany struktury funkcjonalno-przestrzennej jednostek urbanistycznych Wrocławia. Prace Naukowe Uniwersytetu Ekonomicznego we Wrocławiu 490: 160-169.

ZimnY H. (2005): Ekologia miasta. Agencja Reklamowo-Wydawnicza A. Grzegorczyk, Stare Babice. 


\section{APPENDIX}

Table 1. List of the species found arranged according to their requirements in relation to the humidity of the habitat, together with data on their frequency (number of woodlots in which the species was recorded), trophic requirements and assignation to sociological-ecological group

Symbols: trophic requirements: $\mathrm{nn}$ - plants of very rich habitats (Ellenberg index value 8-9), $\mathrm{n}$ - plants of rich habitats (7), mn - plants of moderately rich habitats (4-6), pn - plants of poor habitats (1-3), xn - plants neutral in relation to the fertility of the habitat, ln - no data on trophic requirements; sociological-ecological groups: C - plants of segetal communities, $\mathrm{F}$ - plants of forest communities, $\mathrm{M}-$ meadow plants, TG - plants of warm grassland communities, NW - plants of communities developing near water, OZ - communities of the forests' herbal fringes, $\mathrm{R}$ - plants of ruderal communities, $\mathrm{S}$ - plants of scrub communities, U-O - utility and ornamental plants, $\mathrm{W}$ - aquatic communities; $\mathrm{fF}$ - ancient woodlands indicator; ${ }^{*}$ - alien plants (kenophytes).

\section{HYDROPHYTES $\sum=16$}

Alisma plantago-aquatica L. [1, nn, NW]; Eleocharis palustris (L.) Roem. \& Schult. [1, ln, NW]; Glyceria maxima (Hartm.) Holmb. [8, nn, NW]; Glyceria notata Chevall. [1, nn, NW]; Hottonia palustris L. [4, mn, W]; Lemna minor L. [3, mn, W]; Lemna trisulca L. [1, mn, W]; Oenanthe aquatica (L.) Poir. [5, mn, NW]; Oenanthe fistulosa L. [1, n, NW]; Phragmites australis (Cav.) Trin. ex Steud [22, n, NW]; Rorrippa amphibia (L.) Besser [2, nn, NW]; Rumex hydrolapathum Huds. [5, n, NW]; Salvinia natans (L.) Allioni [1, n, W]; Schoenoplexus lacustris (L.) Palla [1, mn, NW]; Sparganium erectum L. em. Rchb. [3, n, NW]; Typha latifolia L. [3, nn, NW].

$$
\text { HIGROPHYTES } \sum=71
$$

Agrostis canina L. [1, pn, M]; Agrostis gigantea Roth [12, mn, M]; Agrostis stolonifera L. [4, mn, M]; Alnus glutinosa (L.) Gaertn. [33, xn, F]; Alopecurus aequalis Sobol. [1, nn, NW]; Alopecurus geniculatus L. [1, n, M]; Angelica sylvestris L. [6, mn, M]; Athyrium filix-femina (L.) Roth [3, mn, fF]; *Bidens frondosa L. [6, nn, NW]; Carex acutiformis L. [16, mn, NW]; Carex buekii Wimm. [3, mn, NW]; Carex gracilis Curt. [10, mn, NW]; Carex nigra Reichard [1, pn, NW]; Chenopodium chenopodioides (L.) Aellen [1, nn, R]; Circaea intermedia Ehrh. [2, mn, F]; Cucubalus baccifer L. [15, n, S]; Cuscuta europaea L. [3, n, S]; Deschampsia caespitosa (L.) P.B. [13, pn, M]; Epilobium hirsutum L. [4, nn, S]; Epilobium palustre L. [1, pn, NW]; Epilobium parvifolium Schreb. [2, $\mathrm{mn}, \mathrm{S}]$; Equisetum sylvaticum L. [1, mn, fF]; Eupatorium cannabium L. [2, nn, S]; Euphorbia lucida Waldst. et Kit. [3, mn, M]; Festuca gigantea (L.) Vill. [2, mn, fF]; Filipendula ulmaria (L.) Maxim. [16, mn, M]; Frangula alnus Mill. [21, xn, F]; Galium palustre L. [2, mn, NW]; Galium uliginosum L. [2, pn, M]; Glyceria fluitans (L.) R. Br. [9, n, NW]; Humulus lupulus L. [46, nn, S]; Iris pseudoacorus L. [17, n, NW]; Juncus conglomeratus L. [2, pn, M]; Juncus effusus L. [16, mn, M]; Lychnis flos--cuculi L. [1, xn, M]; Lycopus europaeus L. [6, n, NW]; Lysimachia vulgaris L. [24, xn, M]; Lythrum salicaria L. [15, xn, M]; Molinia caerulea (L.) Moench [1, pn, M]; Myosotis palustris Hill. [3, mn, M]; Myosoton aquaticum (L.) Moench [6, nn, S]; Padus avium Mill. [39, mn, F]; Phalaris arundinacea L. [27, n, NW]; Poa trivialis L. [26, n, M]; Polygonum hydropiper L. [4, nn, NW]; Polygonum lapathifolium L. subsp. lapathifolium [2, nn, NW]; Populus nigra L. [7, mn, F]; Ranunculus flammula L. [1, pn, M]; Ranunculus repens L. [8, n, M]; *Reynoutria japonica Houtt. [4, n, R]; Ribes spicatum Robson [5, mn, fF]; Rumex crispus L. [14, mn, M]; Rumex maritimus L. [1, nn, NW]; Salix alba L. [6, mn, F]; Salix cinerea L. [11, mn, F]; Salix fragilis L. [36, mn, F]; Salix rosmarinifolia L. [1, pn, S]; Salix triandra L. [1, mn, S]; Salix viminalis L. [2, xn, S]; Scirpus silvaticus L. [8, mn, M]; Scutellaria galericulata L. [5, mn, NW]; Selinum carvifolia L. [5, pn, M]; Solanum dulcamara L. [6, nn, NW]; Stachys palustris L. [8, mn, M]; Stachys sylvatica L. [4, n, fF]; Stellaria nemorum L. [2, n, fF]; Symphytum officinale L. [25, nn, M]; Ulmus laevis Pall. [17, mn, F]; Valeriana officinalis L. [3, mn, M]; Veronica anagalis-aquatica L. [1, mn, NW]; Veronica longifolia L. [1, mn, M].

$$
\text { XEROPHYTES } \Sigma=20
$$

Anthyllis vulneraria L. [1, pn, M]; Artemisia campestris L. [1, pn, TG]; Asparagus officinalis L. [2, mn, TG]; Berteroa incana (L.) DC. [3, mn, R]; Bromus tectorum L. [1, mn, R]; Dianthus carthusianorum L. [1, pn, TG]; Dianthus deltoides L. [1, pn, TG]; Euphorbia cyparissias L. [15, pn, TG]; Hieracium umbellatum L. [6, pn, OZ]; Medicago falcata L. [2, pn, OZ]; Melilotus officinalis (L.) Pall. [1, pn, R]; Peucedanum oreoselinum (L.) Moench [1, pn, OZ]; Pimpinella saxifraga L. [6, pn, M]; Potentilla argentea L. [6, pn, TG]; Potentilla collina Wibel [2, pn, TG]; ${ }^{*}$ Cerasus mahaleb (L.) Mill. [1, pn, S]; Rosa agrestis Savi [15, pn, S]; Sedum maximum L. [7, pn, OZ]; Trifolium arvense L. [3, pn, TG]; Vincetoxicum hirundinaria Medik. [1, pn, OZ].

$$
\text { NEUTRAL IN RELATION TO CHANGE OF HUMIDITY IN HABITAT } \Sigma=41
$$

Acer platanoides L. [17, xn, F]; Agrostis capillaris L. [15, mn, OZ]; Antoxanthum odoratum L. [1, xn, TG]; Arrhenaterum elatius (L.) P. Beauv. ex J. \& C. Presl [50, n, M]; Atriplex nitens Schkuhr. [2, n, R]; Betonica officinalis L. [2, pn, M]; Betula pendula Roth [28, xn, F]; Bromus hordeaceus L. [2, pn, M]; Calamagrostis epigejos (L.) Roth [46, mn, S]; Carpinus betulus L. [12, xn, F]; Centaurea jacea L. [7, xn, M]; Cirsium arvense (L.) Scop. [42, n, R]; Corylus avellana L. [6, mn, F]; Deschampsia flexuosa L. [1, pn, F]; Dryopteris carthusiana (Vill.) H.P. Fuchs [3, pn, fF]; Elymus repens (L.) Gould [46, n, R]; Equisetum arvense L. [30, pn, R]; Festuca ovina L. [2, pn, TG]; Fraxinus excelsior L. [39, n, F]; Galium aparine L. [44, nn, S]; Geranium robertianum L. [6, n, S]; Matricaria maritima L. subsp. inodora [6, mn, C]; Pinus sylvestris L. [4, xn, F]; Plantago lanceolata L. [6, xn, M]; Polygonum amphibium L. fo. terrestris [8, mn, NW]; Prunus spinosa L. [52, xn, S]; Quercus robur L. [63, $\mathrm{xn}, \mathrm{F}$; Ranunculus acris L. [1, xn, M]; Ribes uva-crispa L. [1, mn, S]; Rubus caesius L. [59, n, S]; Rubus idaeus L. [5, mn, S]; Rumex acetosa L. [9, mn, M]; Salix purpurea L. [3, xn, S]; Silaum silaus (L.) Schinz \& Thell. [5, pn, M]; Sorbus aucuparia L. [8, xn, F]; Ulmus minor Mill. [17, xn, F]; *Solidago canadensis L. [7, mn, S]; Stellaria media (L.) Vill. [15, nn, C]; Viburnum opulus L. [12, mn, F]; Vicia angustifolia L. [2, xn, C]; Viola arvensis Murr. [1, xn, C]. 
The vascular flora ecological diversity in the mid-field woodlots situated on the agricultural outskirts...

\section{MESOPHYTES $\Sigma=223$}

Acer campestre L. [25, mn, F]; Achillea millefonium L. [21, mn, M]; *Acer negundo L. [5, n, S]; Acer pseudoplatanus L. [8, n, F]; Aegopodium podagraria L. [14, nn, fF]; Aethusa cynaphium L. [1, mn, C]; Agrimonia eupatoria L. [15, mn, OZ]; Ajuga reptans L. [6, mn, fF]; Alliaria petiolata (M. Bieb.) Cavara et Grande [39, nn, S]; Allium vineale L. [9, n, S]; Alopecurus pratensis L. [21, n, M]; *Amaranthus retroflexus L. [2, n, R]; ${ }^{*}$ Amelanchier $\times$ lamarckii F.G. Schroed. [1, pn, U-O]; Anchusa arvensis L. [1, mn, C]; Anthriscus sylvestris L. [9, nn, S]; Apera spica-venti L. [5, xn, C]; Arctium lappa L. [9, nn, R]; Arctium minus (Hill) Bernh. [16, nn, R]; Arctium tomentosum Mill. [3, nn, R]; Arenaria serpyllifolia L. [1, xn, TG]; Armoracia rusticana G. Gaertn. et al. [3, nn, R]; Artemisia vulgaris L. [44, nn, R]; Astragalus glycyphyllos L. [6, pn, OZ]; Atriplex patula L. [5, n, C]; Avena fatua L. [4, xn, C]; Ballota nigra L. [30, nn, R]; Bellis perennis L. [1, mn, M]; Brachypodium sylvaticum (Huds.) P. Beauv. [15, mn, fF]; Bromus arvensis L. [2, mn, C]; Bromus inermis Leyss. [14, mn, R]; Bromus ramosus Huds. [1, mn, S]; Bromus sterilis L. [36, mn, R]; *Bryonia alba L. [1, n, R]; *Bryonia dioica Jacq. [2, n, R]; Calamagrostis arundinacea L. Roth. [8, mn, F]; Calystegia sepium (L.) R.Br. [21, nn, S]; Campanula glomerata L. [1, pn, TG]; Campanula trachelium L. [2, nn, fF]; Capsella bursa-pastoris (L.) Medik [2, mn, C]; Carduus acanthoides L. [1, n, R]; Carduus crispus L. [2, nn, R]; Carex hirta L. [25, mn, M]; Carex pairae F.W. Schultz [16, mn, S]; Carex pallescens L. [2, pn, S]; Carex sylvatica Huds. [2, mn, fF]; Carlina vulgaris L. [1, pn, TG]; Centaurium erythraea Rafn [2, mn, S]; Cerastium holosteoides Fr. em. Hyl. [1, mn, M]; Chaerophyllum temulum L. [33, nn, S]; Chamaenerion angustifolium (L.) Schur [1, nn, S]; Chamomilla recutita (L.) Rauschert [1, mn, C]; Chelidonium majus L. [21, nn, S]; Chenopodium album L. [20, n, C]; Chenopodium hybridum L. [1, nn, R]; Chenopodium polyspermum L. [5, nn, C]; *Chenopodium strictum Roth. [2, mn, C]; Cichorium intybus L. [16, mn, R]; Cirsium vulgare (Savi.) Ten. [17, nn, R]; Clinopodium vulgare L. [4, pn, OZ]; Conium maculatum L. [14, nn, R]; Consolida regalis Gray [2, mn, C]; Convallaria majalis L. [5, mn, fF]; Convolvulus arvensis L. [18, xn, R]; *Conyza canadensis (L.) Cronquist [10, mn, R]; Cornus sanguinea L. [21, xn, S]; Crataegus laevigata (Poir.) DC. [3, mn, S]; Crataegus $\times$ macrocarpa Hegetschw. [2, ln, S]; Crataegus monogyna Jacq. [75, pn, S]; Crepis biennis L. [1, mn, M]; Crepis capillaris (L.) Wallr. [2, mn, M ]; Cruciata glabra (L.) Ehrend. [1, mn, S]; *Cydonia oblonga Mill. [1, mn, U-O]; Dactylis glomerata L. [51, mn, M]; Dactylis polygama Horv. [30, mn, fF]; Daucus carota L. [24, mn, M]; Descurainia sophia (L.) Webb ex Prantl [1, mn, R]; Digitaria sanguinalis (L.) Scop. [1, mn, C]; Dryopteris filix-mas (L.) Schott [4, mn, fF]; Echinochloa crus-galli (L.) P. Beauv. [6, nn, C]; Echium vulgare L. [2, mn, R]; Elymus caninus (L.) L. [10, nn, fF]; *Epilobium ciliatum Raf. [2, nn, R]; Epipactis helleborine (L.) Crantz [1, mn, F]; Equisetum pratense Ehrh. [9, pn, M]; *Erigeron annuus (L.) Pers [16, nn, R]; Erodium cicutarium (L.) L`Her. [3, xn, M]; Erysimum cheiranthoides L. [6, n, R]; Euonymus europaea L. [32, mn, fF]; Euphorbia esula L. [4, xn, OZ]; Euphorbia helioscopia L. [3, n, C]; Euphorbia peplus L. [2, n, C]; Fagus sylvatica L. [1, xn, F]; Fallopia convolvulus (L.) Á. Löve [38, mn, C]; Festuca pratensis Huds. [1, mn, M]; Festuca rubra L. [11, xn, M]; Fragaria vesca L. [8, mn, S]; Galeobdolon luteum Huds. [2, mn, fF]; Galeopsis bifida Boenn. [1, nn, S]; Galeopsis pubescens Willd. [10, mn, R]; Galeopsis speciosa Mill. [4, nn, C]; Galeopsis tetrahit L. [18, n, S]; *Galinsoga parviflora Cav. [3, nn, C]; Galium boreale L. [2, pn, M]; Galium mollugo L. [23, ln, M]; Galium verum L. [9, pn, OZ]; Geranium pusillum L. [3, n, C]; Geranium sylvaticum L. [2, n, S]; Geum urbanum L. [59, $\mathrm{n}, \mathrm{S}]$; Glechoma hederacea L. [21, n, S]; Hedera helix L. [4, xn, fF]; *Helianthus tuberosus L. [2, nn, R]; Heracleum sphondylium L. [12, nn, M]; Holcus lanatus L. [17, mn, M]; Holcus mollis L. [2, pn, F]; Hordeum murinum L. [3, mn, R]; Hypericum perforatum L. [44, mn, M]; Hypochoeris radicata L. [1, pn, TG]; *Impatiens parviflora DC. [46, mn, S]; *Juglans regia L. [10, n, U-O]; Lactuca serriola L. [26, mn, R]; Lamium maculatum L. [2, nn, S]; Lamium purpureum L. [1, n, C]; Lapsana communis L. [13, n, S]; Lathyrus latifolius L. [2, pn, OZ]; Lathyrus pratensis L. [7, mn, M]; Lathyrus tuberosus L. [3, mn, R]; Leontodon autumnalis L. [1, mn, M]; Leonurus cardiaca L. [8, nn, R]; Leucanthemum vulgare Lam. [1, pn, M]; Ligustrum vulgare L. [9, pn, S]; Linaria vulgaris L. [10, mn, R]; *Lolium multiflorum Lam. [4, nn, U-O]; Lolium perenne L. [10, n, M]; Lonicera xylosteum L. [2, mn, F]; Lotus corniculatus L. [3, pn, M]; Luzula campestris (L.) DC. [1, pn, OZ]; Lysimachia nummularia L. [15, xn, M]; Maianthemum bifolium (L.) DC. [1, pn, fF]; Malva sylvestris L. [2, nn, R]; Malus sylvestris (L.) Mill. [14, mn, F]; Medicago lupulina L. [5, xn, TG]; *Medicago sativa L. [2, xn, R]; Melampyrum nemorosum L. [10, mn, fOZ]; Melandrium album (Mill.) Garcke [11, n, R]; Melica nutans L. [2, pn, fF]; Milium effusum L. [9, mn, fF]; Moehringia trinervia (L.) Clairv. [13, n, fF]; Myosotis arvensis (L.) Hill [2, mn, C]; ${ }^{*}$ Oenothera biennis L. [3, mn, R]; Oxalis acetosella L. [1, mn, fF]; *Oxalis fontana Bunge $[5, \mathrm{n}, \mathrm{C}] ;$ * Padus serotina Ehrh. [40, $\ln , \mathrm{F}]$; Papaver dubium $\mathrm{L} .[1$, mn, R]; Papaver rhoeas L. [2, mn, C]; Pastinaca sativa L. [4, mn, M]; Phleum pratense L. [16, n, M]; Picris hieracioides L. [5, mn, R]; Pimpinella major L. Huds [1, mn, M]; Plantago major L. [7, mn, R]; Poa annua L. [1, nn, M]; Poa nemoralis L. [30, mn, fF]; Poa pratensis L. [17, mn, M]; Polygonatum multiflorum (L.) All. [4, mn, fF]; Polygonum aviculare L. [13, mn, C]; Polygonum persicaria L. [3, n, C]; Populus alba L. [10, mn, F]; Populus tremula L. [26, xn, S]; *Portulaca oleracea L. [1, n, R]; Potentilla anserina L. [6, n, M]; Potentilla reptans L. [21, mn, M]; Prunella vulgaris L. [1, xn, M]; Prunus avium L. [36, mn, F]; Pulmonaria obscura Dumort. [2, n, fF]; *Pyrus communis L. [28, xn, U-O]; Pyrus pyraster (L.) Burgsd. [2, ln, S]; Ranunculus polyanthemos L. [1, pn, F]; Reseda lutea L. [1, mn, R]; Rhamnus catharticus L. [12, mn, S]; *Robinia pseudoacaccia L. [19, nn, F]; Rosa arvensis Huds. [4, mn, S]; Rosa canina L. [13, xn, S]; Rubus fruticosus L. [32, pn, S]; Rumex obtusifolius L. [2, nn, R]; Salix caprea L. [9, n, S]; Sambucus nigra L. [69, nn, S]; Sambucus racemosa L. [2, nn, S]; Sanguisorbia officinalis L. [7, mn, M]; Saponaria officinalis L. [5, mn, R]; Scrophularia nodosa L. [22, n, fF]; Senecio jacobaea L. [6, mn, R]; Setaria glauca (L.) Beauv. [3, mn, C]; *Sisymbrium loeselii L. [15, mn, R]; Sisymbrium officinale (L.) Scop. [1, n, R]; Solanum nigrum L. [1, nn, R]; *Solidago gigantea Aiton [67, n, R]; Solidago virgaurea L. [2, mn, fF]; Sonchus asper (L.) Hill. [1, n, C]; Sonchus oleraceus L. [4, nn, C]; Stellaria graminea L. [4, pn, M]; Tanacetum vulgare L. [34, mn, R]; Taraxacum officinale F.H. Wigg. [11, nn, M]; Thlaspi arvense L. [3, mn, C]; Tilia cordata Mill. [19, mn, F]; Tilia platyphyllos Scop. [5, n, F]; Torilis japonica D.C. [31, nn, S]; Tragopogon pratensis L. [1, mn, M]; Trifolium campestre Schreb. [1, pn, TG]; Trifolium medium L. [4, pn, OZ]; Trifolium pratense L. [4, xn, M]; Trifolium repens L. [4, mn, M]; Tussilago farfara L. [3, xn, R]; Urtica dioica L. [68, nn, R]; Verbascum densiflorum Bertol. [1, mn, R]; Verbascum thapsus L. [1, n, R]; Verbena officinalis L. [2, n, R]; Veronica chamaedrys L. [10, mn, M]; Vicia cracca L. [26, xn, M]; Vicia hirsuta (L.) Gray [7, mn, C]; Vicia sepium L. [1, mn, OZ]; Vicia tetrasperma (L.) Schreb. [1, mn, C]; Vicia villosa Roth. [6, mn, C]; Viola odorata L. [2, nn, S]; Viola reichenbachiana Jordan ex Bor. [12, mn, fF].

$$
\text { SPECIES OF NOT DEFINED BY ELLENBERG et al. (2001) REQUIREMENTS TO HUMIDITY } \sum=32
$$

${ }^{*}$ Aesculus hippocastanum L. [7, $\left.\ln , \mathrm{U}-\mathrm{O}\right] ;{ }^{*}$ Aronia melanocarpa (Michx.) Elliott [1, ln, U-O]; Avena sativa L. [1, $\left.\ln , \mathrm{U}-\mathrm{O}\right]$; *Cerasus vulgaris Mill. [2, ln, U-O]; *Fraxinus latifolia Benth. [3, ln, U-O]; *Ipomoea purpurea (L.) Roth [1, ln, U-O]; Iris germanica L. [2, ln, U-O]; Linum usitatissimum L. [1, ln, U-O]; * 'Lycopersicon esculentum (L.) Karst. ex Farw. [1, ln, U-O]; *Malus domestica Borkh. [14, ln, U-O]; ${ }^{*}$ Miscanthus sacchariflorus (Maxim.) Hack. [1, ln, U-O]; *Morus alba L. [2, ln, U-O]; *Parthenocissus inserta (A. Kern.) Fritsch [9, ln, U-O]; *Populus $\times$ canadensis Moench $[2, \ln , \mathrm{U}-\mathrm{O}]$; * Prunus cerasifera Ehrh. [20, ln, U-O]; *Prunus domestica L. [7, ln, U-O]; Prunus domestica L. subsp. syriaca (Borkh.) Janch [9, In, U-O]; *Quercus palustris Münchh. [1, ln, U-O]; *Quercus rubra L. [5, ln, F]; *Reynoutria $\times$ bohemica Chrtek \& Chrtkova. [2, ln, R]; *Rhus typhina L. [1, ln, U-O]; *Rosa multiflora Thunb. [4, ln, U-O]; *Rosa rugosa Thunb. [1, $\ln , \mathrm{U}-\mathrm{O}]$; Salix $\times$ fruticosa Döll. [1, ln, U-O]; Salix $\times$ multinervis Döll. [8, ln, S]; Salix $\times$ reichardtii A.Kern. [2, ln, S]; Secale cereale L. [1, ln, U-O]; *Sida hermaphrodita (L.) Rusby [1, ln, U-O]; *Silybum marianum (L.) Gaertner [1, ln, U-O]; *Sorbaria sorbifolia (L.) A. Br [2, ln, U-O]; *Symphoricarpos albus Duhamel [4, ln, U-O]; Triticum aestivum L. [2, ln, U-O]. 